\title{
RSSDI's Defeat Diabetes Campaign: India takes a major leap in the direction of diabetes care capital of the world
}

\author{
Banshi Saboo ${ }^{1} \cdot$ Rakesh M. Parikh² \\ Published online: 14 December 2021 \\ (c) The Author(s), under exclusive licence to Research Society for Study of Diabetes in India 2021
}

Before the country could recover from the first wave of COVID-19 pandemic, India witnessed a sharp rise in number of cases in the month of March 2021. The number of new cases in a single day reached its peak on 4,12,431, during the first week of May 2021. The effects have been devastating with close to half a million deaths as per the official data. Several studies have demonstrated that the risk of severe infection, respiratory distress syndrome, and mortality has been significantly higher in people with diabetes [1-4]. Even people with prediabetes and undiagnosed diabetes $[5,6]$ were found to be at a significantly higher risk of severe infection and mortality due to COVID-19 infection.

India has estimated 77 million people living with diabetes, and an even larger number of people with prediabetes. Various studies have also reported that $50 \%$ of people with diabetes are unaware of the condition. This unholy interaction of two ongoing pandemics-diabetes and COVID-19has baffled medical professionals and organizations worldwide. With such a high prevalence of diabetes and its strong association with COVID-19 mortality, it is imperative that creating awareness in general public could save a lot of lives.

\section{Defeat Diabetes Campaign}

Research Society for Study of Diabetes in India (RSSDI), being the largest organization of professionals involved in the care of people with diabetes, decided to launch a massive public awareness campaign. In the second week of June 2021, a task force was created which further identified

Banshi Saboo

banshisaboo98@gmail.com

Rakesh M. Parikh

drrakeshparikh@gmail.com

1 DiaCare-Diabetes Care and Hormonal Clinic, Ahmedabad, Gujarat, India

2 Diabecity, Jaipur, Rajasthan, India hundreds of RSSDI members who volunteered to be the ambassadors for the campaign. The goal was set to reach a hundred million people in the next 100 days with a tagline of Test, Track, and Treat.

WhatsApp messaging service was used as the channel for percolating content and information to the grassroot levels. Several WhatsApp groups were created by the task force members and ambassadors. For bulk sharing of the content received through this network, various social media platforms like Facebook, Twitter, Instagram, and YouTube were used. Various creatives that would catch the attention of general people and educate them regarding various aspects of diabetes were designed and shared through social media platforms on a daily basis.

Live video sessions for public awareness were done on a daily basis using various social media platforms. A number of community reach activities were also conducted locally by the ambassadors. These activities were being covered by local print and electronic media. Influential people from various spheres of life including social activists, politicians, bureaucrats, and Bollywood celebrities contributed to the campaign by posting about the same on their social media handles. Some of them joined the weekly live event of RSSDI-Diabetes Bytes. A separate FM campaign was launched in all major cities of India. Audio bytes of 20-40 doctors from each city were broadcasted through FM, 6 slots a day for one week.

Based on the conclusions of a systematic review by Kesavadev et al. [7], an online petition addressed to Director, WHO_- "Declare Blood Sugar as Fifth Vital Sign" was published [8] and circulated among doctors.

\section{Campaign analysis}

After completion of 75 days of the 100-day campaign, interim analysis of its reach through social media was performed using online social media analytic tool "Brand 
Mentions." The analysis concluded that the campaign reach had been 123.3 million between 1 July and $23 \mathrm{Sept}$ with 1747 mentions, 230.5 thousand interactions, 26.5 thousand shares, and 203.7 thousand likes. Major sources of this were Twitter and Instagram contributing to $77.68 \%$ and $21.18 \%$, respectively. It was impossible to estimate its reach on diverse platforms like WhatsApp, FM Campaign, Print Media, and Community programs.

\section{One Nation, One Day, One Million Tests}

As part of the campaign, a massive nationwide blood sugar testing camp was planned. Rotary India, an organization with huge volunteer base, was approached, and they agreed to partner with RSSDI for this historic event. With RSSDI being a huge organization, the information related to this mega event was passed on to 21 state chapters and 700 district coordinators.

A geolocation-based webapp was developed. Doctors from all over India and clubs of Rotary India were registered on the app. A separate portal to capture a few basic parameters from history, anthropometry, and blood sugar levels was developed. This being the first attempt to check around 1 million people in one day, Asia Book of Records was approached and all their requirements for considering this as a record were fulfilled.

On the day of the event, data of over 1.1 million blood sugar tests were received, target being 1 million blood sugar tests in one day. The data was later verified by validators from Asia Book of Records and has now been published as a record for participation of maximum people in diabetes screening camps held at multiple venues in one day [9]. As published in Asia Book of Records, a total number of 10,64,989 people were screened for diabetes across 10,258 camps conducted on September 29, 2021.

\section{Potential impact}

Over a hundred million people have been educated regarding importance of screening for diabetes (test), regular monitoring of diabetes (track), and treatment to maintain glycemic control (treat). With nationwide camps, a large number of people, who were undiagnosed earlier, have been detected to be diabetic. This would surely translate into preventing complications and saving thousands of lives. The partner organizations also realized that there is a huge untapped potential that can be utilized in the future for such activities.

\section{Campaign to movement-the way forward}

This campaign witnessed an unprecedented enthusiasm from medical professionals and volunteers. During various meetings related to the campaign, it was suggested that this campaign had gradually taken the shape of a movement. The two largest partnering organizations, RSSDI and Rotary India, signed a memorandum of understanding for three years to continue with similar activities in the future. Defeat Diabetes Campaign was a first major leap in the direction of making India a diabetes care capital of the world.

\section{Conclusion}

The grand success of the Defeat Diabetes Campaign and Mammoth One Nation, One Day, One Million Blood Sugar Tests confirms that a coordinated and meticulously executed campaign by healthcare professionals and other voluntary organizations along with the use of technology can contribute to the cause of public awareness in a big way.

Acknowledgments Our sincere thanks to Dr.Sanjay Agrawal (Hon. secretary RSSDI), Dr. Ch.Vasanth Kumar (Hon. President RSSDI). We extend our gratitude towards RSSDI task force members, Dr. Amit Gupta, Dr. Rajiv Kovil, Dr. Supratik bhattacharyya, Dr.Nandita Arun, Dr.Sachin Chittawarand Dr. Purvi Chawla.

\section{References}

1. Raghavan A, Nanditha A, Satheesh K, Susairaj P, Vinitha R, Chandrasekaran S, et al. Profile and prognosis of patients hospitalized for COVID-19 virus infection with and without diabetesan observational study from South India. Diabetes Metab Syndr. 2021. https://doi.org/10.1016/j.dsx.2021.05.016.

2. Pal R, Bhadada SK. COVID-19 and diabetes mellitus: an unholy interaction of two pandemics. Diabetes Metab Syndr. 2020;14:513-7 [PMC free article] [PubMed] [Google Scholar].

3. Singh AK, Singh R. Does poor glucose control increase the severity and mortality in patients with diabetes and COVID-19? Diabetes Metab Syndr. 2020;14:725-7.

4. Corona G, Pizzocaro A, Vena W, Rastrelli G, Semeraro F, Isidori AM. Diabetes is most important cause for mortality in COVID-19 hospitalized patients: systematic review and meta-analysis. http:// link.springer.com/10.1007/s11154-021-09630-8 Rev Endocr Metab Disord [Internet]. 2021 [cited 2021 Apr 23]; Available from: [PMC free article] [PubMed].

5. Smith S.M., Boppana A., Traupman J.A., Unson E., Maddock D.A., Chao K., Dobesh D.P., Brufsky A., Connor R.I. Impaired glucose metabolism in patients with diabetes, prediabetes, and obesity is associated with severe COVID-19. J. Med. Virol. 2020. https://doi.org/10.1002/jmv.26227. [PMC free article] [PubMed] [CrossRef] [Google Scholar].

6. Vargas-Vázquez A, Bello-Chavolla OY, Ortiz-Brizuela E, et al. Impact of undiagnosed type 2 diabetes and pre-diabetes on severity and mortality for SARS-CoV-2 infection. BMJ Open 
Diabetes Res Care. 2021;9:e002026. https://doi.org/10.1136/ bmjdrc-2020-002026.

7. Kesavadev J, Misra A, Saboo B, Aravind SR, Hussain A, Czupryniak L, Raz I. Blood glucose levels should be considered as a new vital sign indicative of prognosis during hospitalization. Diabetes Metab Syndr. 2021;15(1):221-7. https://doi.org/10.1016/j. dsx.2020.12.032.

8. Parikh RM. Declare blood sugar as fifth vital sign. https://www. change.org/defeatdiabetes accessed on 30 Oct 2021.

9. Asia book of records. Participation of maximum people in diabetes screening camps held at multiple venues in one day. https:// www.asiabookofrecords.com/participation-of-maximum-peoplein-diabetes-screening-camps-held-at-multiple-venues-in-one-day/ accessed on 30 Oct 2021.

Publisher's note Springer Nature remains neutral with regard to jurisdictional claims in published maps and institutional affiliations. 